\title{
DERIVING BIOLOGICALLY ACTIVE PEPTIDES AND STUDY OF THEIR QUALITIES
}

\author{
Irina S. Milentevaa, ${ }^{\mathrm{a},}$, Lyubov S. Dyshlyuka, Alexandr Yu. Prosekov ${ }^{\mathrm{b}}$, Olga O. Babich ${ }^{\mathrm{b}}$, Mikhail V. Shishin ${ }^{\mathrm{a}}$ \\ ${ }^{a}$ Kemerovo Institute of Food Science and Technology (University), \\ Stroiteley blvd. 47, Kemerovo, 650056 Russian Federation \\ ${ }^{\mathrm{b}}$ Kemerovo State University, \\ Krasnaya Str. 6, Kemerovo, 650043 Russian Federation \\ * e-mail: irazumnikova@mail.ru
}

Received May 1, 2016;

Accepted in revised form June 25, 2016;

Published December 30, 2016

\begin{abstract}
The main component of human health is nutrition which becomes even more important if a person is sick. In the body of cancer patients metabolic processes change, so he/she requires a special diet. Probiotics and short peptides are the integral part of the diet of cancer patients. One of the goals of nutritional support for cancer patients is the visceral protein pool maintenance. In modern formulae for enteral support for cancer patients the protein component can be represented in one of three types: native protein; cow's milk whey/whole protein peptides; free amino acids. The present article deals with study on biotechnological treatment influence on milk protein controlled hydrolysis process with the aim of deriving biologically active peptides, as well as of studying several qualities: immunomodulatory, cytotoxic, antioxidant and prebiotic. Conditions for enzymic hydrolysis of milk proteins are optimised, which provide deriving biologically active directional peptides. The optimal parameters of hydrolysis conduction are chosen, which provide the polypeptide chain division into peptides and free amino acids, as well as enzymic system was chosen, consisting of chymotrypsin or thermolysin at a temperature of $37 \pm 2^{\circ} \mathrm{C}$, in the enzyme-substrate ratio of 1 to 50 and process time of $12.00 \pm 0.05 \mathrm{~h}$. The qualities of biologically active peptides (immunomodulatory, cytotoxic, antioxidant and prebiotic), derived from milk proteins, are studied. The studies demonstrated that all peptides under study have anti-tumour qualities, at the same time increase in biopeptide concentration causes decrease in the capacity for survival of different line cancer cells.
\end{abstract}

Keywords: milk protein, biologically active peptides, enzymic hydrolysis, biotechnological methods; immunomodulatory qualities, cytotoxic qualities, antioxidant qualities, prebiotic qualities

DOI: $10.21603 / 2500-1418-2016-1-2-20-33$.

\section{INTRODUCTION}

The healthy and balanced foodstuff industrial production is one of the most important problems faced by humankind. In the modern Russia under the conditions of difficult demographic situation, elaboration of efficient and cost-effective approaches to the accelerated population recovery is becoming one of the scientific and applied areas of highest priority, which is specified in «Koncepciya gosudarstvennoi politiki v oblasti zdorovogo pitaniia naseleniia Rossii na period do 2020 goda» [the Public Policy Concept in the sphere of healthy nutrition of the Russian population up to 2020], approved by the government. The largescale introduction into the human everyday life of the functional foodstuffs with eubiotics, preserving and stimulating the natural mechanisms of the human organism protection against unfavourable environmental factors of different nature, should play an important role in realisation of this area $[1,2]$.

The relevance of the chosen area of the studies is beyond doubts. In recent years the concept of human symbiotic microbiota participation in maintenance of human health and in the occurrence of many diseases is becoming more popular [23]. In this area the main objective of the studies is to work out functional foodstuffs for nutritional support for cancer patients during rehabilitation period.

Cancer diseases have one of the central places in the morbidity and mortality structure. They are the most important medical and social problem in most countries, including the Russian Federation. Annually worldwide there are approximately $10 \mathrm{~m}$ new cases of malignant neoplasms and more than $6 \mathrm{~m}$ cases of death from different cancer diseases. In the European countries malignant neoplasms are the second most important reason for death after the cardiovascular diseases. According to the World Health Organisation (WHO), approximately one third of deaths from cancer worldwide is caused by malnutrition and diet has the second place after tobacco as a theoretically preventable cause of cancer [17].

In recent decade people are changing their attitude towards cancer diseases and this has significantly improved their treatment results and life quality. Moreover, a substantial role is occupied by maintenance therapy which includes different life support methods of a cancer patient during treatment, as well as after it.

It is well known that tumour pathological process is accompanied by nutritional deficienc. According to the

Please cite this article in press as: Milenteva I.S., Dyshlyuk L.S., Prosekov A.Yu., Babich O.O., Shishin M.V. Deriving biologically active peptides and study of their qualities. Science Evolution, 2016, vol. 1, no. 2, pp. 20-33. doi: 10.21603/2500-4239-2016-1-2-20-33.

Copyright (C) 2016, KemSU. This is an open access article distributed under the terms of the Creative Commons Attribution 4.0 International License (http:// creativecommons.org/licenses/by/4.0/), allowing third parties to copy and redistribute the material in any medium or format and to remix, transform, and build upon the material for any purpose, even commercially, provided the original work is properly cited and states its license. This article is published with open access at http:// science-evolution.ru/ 
ESPEN report (European Society for Clinical Nutrition and Metabolism, 2000), nutritional deficiency frequency for cancer patients varies from 46 to $88 \%$. The research, performed by the group ECOG in 2003, which included 3047 cancer patients, demonstrated that nutritional deficiency frequency in tumour lesion of gastrointestinal tract (GI tract) organs varies from 70 to $83 \%$. Most often nutritional deficiency is found when there is stomach and pancreas cancer (75-80\%), tumour localisation in lungs, colon, prostate (54-64\%), mammary gland, when there are different sarcomas, haematopoietic and lymphoid malignancies (31-40\%). Nutritional deficiency can be an immediate cause of death for 4 out of 20 cancer patients when it reaches its maximum manifestation in anorexia-cachexia syndrome. In the recent studies it was demonstrated that there is a direct correlation between nutritional deficiency and the survival median, in particular, for patients with colorectal cancer. It should be noted that the anorexia-cachexia syndrome worsens or progresses during the combination therapy - this is the so called anorexia-cachexia iatrogenic syndrome. During treatment $45 \%$ of patients may lose body weight $>10 \%$ [3].

The diet status control regulation and the opportune nutritional support for cancer patients are proved by many studies. The main goal of nutritional support for cancer patients is the visceral protein pool maintenance. As a rule, in formulae for enteral support for cancer patients, produced by different producers, the protein component is presented in the form of native protein, cow's milk whey/whole protein peptides or in the form of free amino acids $[1,4,5]$.

Biologically active peptides have an important role in the protein nutrition of cancer patients. Peptide complexes are short amino acid chains initially extracted from animal organs and tissues and then artificially recreated in laboratory [24].

Peptides biological value lies in their ability to recover functional disorder and prevent pathological processes in the organs and tissues from which they have been initially extracted. Peptides biological activity is extremely wide. Peptides can influence cardiovascular, reproductive, immune, endocrine, digestive and other systems, change the energy exchange in organism, but they are especially effective in the central nervous system activity regulation. Peptides can also have polyfunctionality, i. e. the same peptide can modulate several body systems activity. Moreover, their fragments, appearing during decay in organism, can have their own physiological activity $[6,7]$.

The native protein use in nutritional formulae for cancer patients should be considered inappropriate because a number of terms are required for its use, firstl, cavitary and parietal digestion normalisation. Besides, a large (in comparison with other types) mass of native protein decreases the tolerance level and slows down significantly the absorption speed

Formulae with free amino acids can be more preferable due to main component low molecular mass which obviously indicates a high speed of absorption. But even under ordinary conditions two thirds of nitrogen are absorbed in the form of peptides in intestine (peptides have independent mechanisms of passive transport, but free amino acids are transported by specifically active transport systems), but under the conditions of stress and progressive starvation this indicator is even higher for absorbable peptides and this reduces sharply the effectiveness of the nutritional formula based on free amino acids [25]. There is evidence that formulae based on amino acids, as well as parenteral nutrition and starvation, result in intestine mucosa atrophy [9].

In turn, when peptides get into intestine, they can be absorbed through the villi membranes either with the use of carrier molecules, or diffusely through the lipid sections in membranes. Peptide absorption does not require enzyme activity on the part of pancreas. The currently available data prove that the peptide diet supports liver more effectively and, consequently, it contributes to visceral protein synthesis [3].

Thus, application of nutritional support for cancer patients should be opportune, adequate and rational. This approach allows to protect a patient from progressive body weight loss, improve life quality and conduct more adequate treatment $[1,15]$.

The objective of the studies was to derive biologically active peptides from milk protein and the study of their immunomodulatory, cytotoxic, antioxidant and prebiotic qualities.

\section{OBJECTS AND METHODS}

The following reagents are used in carrying out the study: dipotassium phosphate in accordance with GOST 2493-75; potassium dihydrogen phosphate in accordance with GOST 4198-75; casein in accordance with GOST R 53667-2009; trypsin from pig pancreas (Sigma, USA) with the activity of $250 \mathrm{p} / \mathrm{mg}$ of protein; chymotrypsin from bull pancreas (Sigma, USA) with the activity of $50 \mathrm{p} / \mathrm{mg}$ of protein; thermolysin (Serva, Germany).

Experiments are conducted at the Biotechnology research institute of KemIFST [Kemerovo Institute of Food Science and Technology (University)]. Sampling was conducted in accordance with GOST 18321-73 and GOST 28495-90.

Casein peptide bonds enzymic hydrolysis was conducted by proteolytic enzymes: trypsin, chymotrypsin and thermolysin. The technological process of deriving biologically active peptides from milk proteins is conducted according to the scheme, represented in Fig. 1. It includes the following operations: acceptance, quality assessment, raw materials preparation; addition of phosphates; casein dilution; bringing $\mathrm{pH}$ to 7.5 ; pasteurisation at a temperature of $74 \pm 2^{\circ} \mathrm{C}$ with retention during 15-20 seconds, aimed at destructing microorganisms contained in casein, cooling to a temperature of $37+2^{\circ} \mathrm{C}$, addition of enzymic system containing trypsin, chymotrypsin and thermolysin.

Enzymic hydrolysis is conducted under the following parameters: temperature of $37+2^{\circ} \mathrm{C}$, duration $8.00 \pm 0.05 \mathrm{~h}, \mathrm{pH} 7.5 \pm 0,1 \mathrm{~h}$, enzyme-substrate ratio of 1 to 50 . To avoid the outside microbiota growth and 
bad smell appearance, before the fermentation process beginning $0.5 \%$ toluene is added which then evaporates completely during inactivation process. For the purpose of enzyme complex inactivation and of pathogenic microbiota removal, the obtained hydrolyzate is heated to $95 \pm 2^{\circ} \mathrm{C}$ during 30 seconds.

The peptide formula ultrafiltra ion was conducted using the device MFU-R-45-300 (Russia) through membranes with pore diameter of 10 and $15 \mathrm{KDa}$ at $\mathrm{pH}$ of 6.0-6.5. The obtained filtrate was further subject to sterilisation, with further thickening to dry substances content of $50-55 \%$, and dried to a moisture content of $14-16 \%$.

In the second purification method $300 \mathrm{~g}$ of Sephadex G-25 were added to 11 of casein enzymic hydrolyzate, and left for 10 minutes, then the formula was centrifuged at $3000 \mathrm{rpm}$ during 20 minutes. The supernatant solution was removed, the turgid gel was eluated with distilled water and centrifuged again at $3000 \mathrm{rpm}$ during 20 minutes. The obtained liquid fractions were sterilised with filtration through fine-pored filters with pore diameter of $0.2 \mu \mathrm{m}$. The fractions were subject to cool dehumidification to get the dry forms. The low-molecular-weight peptides presence in fraction was checked with Laemmli electrophoretic method in polyacrylamide gel.

The third scheme of peptide purification was conducted as follows. At the first stage casein enzymic hydrolyzates were subject to ultrafiltration with the device MFU-R-45-300 (Russia). Then, to separate proteins using preparative electrophoresis, the obtained formula containing peptides and low-molecular-weight proteins with mass less than 10-12 kDa, was applied to electrophoresis column (after adding urea to the sample to a concentration of $3 \mathrm{M}$ ). With continuous elution of proteins preparative electrophoresis was conducted in $12.5 \%$ polyacrylamide gel in acid buffer system in the presence of urea in the chamber, produced by the company Bio-Rad (USA). Protein fractions, eluted from the column, were analysed using analytical electrophoresis in the presence of sodium dodecyl sulfate. Then peptides, contained in protein fractions, were separated on chromatograph LC-20 (Shimadzu, Japan) using several consequent cycles of reversedphase high-performance liquid chromatography (RP HPLC), eluating peptides in acetonitrile concentration gradient using different counterions. Fractions, obtained after RP HPLC, were dried using centrifugation under vacuum with the use of the device SpeedVac (Savant, USA).

Technological process indexes control of deriving biologically active peptides is conducted as follows:

Biologically active peptides prebiotic qualities were tested in accordance with the Batch Culture Fermentation method in vitro (bacteria fermentation in one cycle) $[15,16]$.

Bioreactors with cooling $(300 \mathrm{ml})$ are filled with 135 $\mathrm{ml}$ of pre-sterilised basal medium for bacteria growth ( $2 \mathrm{~g} / \mathrm{l}$ of peptone water, $2 \mathrm{~g} / \mathrm{l}$ of yeast extract, $0.1 \mathrm{~g} / \mathrm{l}$ of $\mathrm{NaCl}, 0.04 \mathrm{~g} / \mathrm{l}$ of $\mathrm{K}_{2} \mathrm{HPO}_{4}, 0.04 \mathrm{~g} / \mathrm{l}$ of $\mathrm{KH}_{2} \mathrm{PO}_{4}, 0.01$ $\mathrm{g} / \mathrm{l}$ of $\mathrm{MgSO}_{4} \cdot 7 \mathrm{H}_{2} \mathrm{O}, 0.01 \mathrm{~g} / 1$ of $\mathrm{CaCl}_{2} \cdot 6 \mathrm{H}_{2} \mathrm{O}, 2 \mathrm{~g} / \mathrm{l}$ of
$\mathrm{NaHCO}_{3}, 2 \mathrm{ml}$ of tween $80,0.02 \mathrm{~g} / 1$ of hemin, $0.5 \mathrm{~g} / \mathrm{l}$ of cysteine HCL, $0.5 \mathrm{~g} / \mathrm{l}$ of bile salts, $\mathrm{pH}$ is 7.0 ) and $15 \mathrm{ml}$ of biologically active peptides, derived from milk proteins, are inoculated with $\mathrm{pH}$ of 7.0. Biologically active peptides are added to get a final concentration of $1 \%$ (mass/volume). The control experiment is conducted without adding biologically active peptides, derived from milk proteins, to fermenter. The experiment goes on with constant stir with stir bar, the reaction temperature is $37^{\circ} \mathrm{C}, \mathrm{pH}$ is 6.8 . Anaerobic conditions are maintained by fermenter bubbling in oxygen-free nitrogen atmosphere at $5 \mathrm{ml} / \mathrm{min}$. Samples $(5 \mathrm{ml})$ are selected every $0,4,8$ and 24 hours for bacteria counting and fatty acids analysis. The experiment is conducted in three repeats.

Prebiotic index (PI) was defined by numerical change of two bacterial groups (bifidobacteria, lactobacilli) [17]. During the exponential phase nutrients are in excess and the bacterial growth is maximum ( $\mu$ max). Thus, $\mu$ max describes the bacterial growth extent under specific conditions and is different for different bacteria and substrates.

The change in bacteria number can be calculated using the prebiotic index equation expressed through $\mu_{\max }$ :

$$
P I=\mu_{\max } B i f+\mu_{\max } L a c
$$

where $\mu_{\max }$ is the maximum bacterial growth coefficient in exponential phase; Bif is the bifidobacteria cells number; $L a c$ is the lactobacteria cells number.

Biologically active peptides cytotoxic qualities are tested in vitro on the following cancer cell lines: Burkitt's lymphoma LBR2, human prostate cancer DU 145, human breast cancer MDAMB-231 and MCF7, hepatocellular carcinoma HepG2, brain cancer U-87, human pancreas cancer PANC-1. Calculation of the living cells number in holes after the end of the period of incubation with biologically active peptides is performed with the MTT-colorimetric assay.

Cells are cultivated at a temperature of $37^{\circ} \mathrm{C}$ and $5 \% \mathrm{CO}_{2}$ in the RPMI 1640 medium (PanEco, Russian Federation) which contains $10 \%$ of fetal bovine serum (HyClone Laboratories, Logan, UK), inactivated at a temperature of $56^{\circ} \mathrm{C}$ during 30 minutes, $2 \mathrm{mM}$ of L-glutamine, $100 \mathrm{mcg} / \mathrm{ml}$ of penicillin and $100 \mathrm{mcg} / \mathrm{ml}$ of streptomycin sulphate (PanEco, Russian Federation). Cells light microscopy is conducted using the AxioVision 4 system (Zeiss, Germany). Cells viability is determined by the trypan blue dye (PanEco, Russian Federation) exclusion in the Goryaev's chamber.

Malignant cells, reached the logarithmic growth phase, are stabilised in 96-hole micro-tablets ("Costar"), $5 \cdot 10^{4}-6.5 \cdot 10^{4}$ cells per hole, and pre-incubated during 24 hours before the addition of biologically active peptides under test under the conditions of $5 \% \mathrm{CO}_{2}$ and $37^{\circ} \mathrm{C}$. The obtained cell cultures in a wide range of progressively decreasing concentrations are added to the holes with biologically active peptides $(20 \mathrm{mkL}$ to $180 \mathrm{mkL}$ of cellular suspension) and co-incubated during 48 hours. Normal saline is added to the control holes in the adequate volume $(20 \mathrm{mkL})$. After the incubation period 
end the living cells number is defined with the MTTcolometrical assay based on living cells dehydrogenase capability to recover 3-(4,5-dimethylthiazol-2-yl)-2,5diphenyltetrazolium bromide (MTT) to violet formazan crystals, diluted in dimethyl sulfoxide. Then optical absorption of dimethyl sulfoxide stained solutions is measured on the tablet photometer Multiskan MS (Labsystem, Finland) at $\lambda=540 \mathrm{~nm}$.

Cytotoxicity of biologically active peptides

under test is assessed according to the formula:

$$
\left(1-N_{o} / N_{k}\right) \cdot 100 \%
$$

where $N_{o}$ is the optical absorption in the test samples, $N_{k}$ is the optical absorption in control.

Biologically active peptides cytotoxic qualities are tested in vivo on the rat spleen splenocytes of the certified line Sprague-Dawley or Wistar. The result is defined accordi $\mathrm{g}$ to the complex parameters of the animal state, as well as according to the living cells number in the rat spleen cutoff and to the general organ appearance [18].

The peptide drug is once administered in several ways (intravenously, intraperitoneally, orally). Normal saline is administered to the control animal group in the same way. The total duration of animal observation should be at least 7 days. Daily registration is required for animal death, body weight and presence or absence of possible intoxication clinical symptoms, including ataxia, hair and skin condition, mucous membrane colour and tail position. After 24 hours and 7 days splenocytes of the survived animals are taken, at least 5 animals respectively. Obligatory examination is required for all animals died during the observation period. Then histological and cellular tests of both survived and dead animals are conducted. The animals are decapitated, their spleen is removed, cutoffs for histological test are made and the spleen is homogenised. Splenocyte suspencion in the RPMI-1640 medium containing $10 \%$ of fetal bovine serum (HyClone Laboratories, Logan, UK), inactivated at a temperature of $56^{\circ} \mathrm{C}$ during 30 minutes, $2 \mathrm{mM}$ of L-glutamine, 100 $\mathrm{mcg} / \mathrm{ml}$ of penicillin and $100 \mathrm{mcg} / \mathrm{ml}$ of streptomycin sulphate (PanEco, Russian Federation) is filtered, treated with $0.3 \% \mathrm{NH} 4 \mathrm{Cl}$ solution for erythrocyte lyzing, centrifuged and re-suspended in the same medium. Then the cell colour and assay are analysed.

Slide preparation is conducted at histological test. Small pieces $(0.5 \times 1 \times 1 \mathrm{~cm})$ are cut off the corresponding organ and placed into fixativ (formalin, methanol etc.) usually for 24 hours. After the fixativ the samples are washed with running water during several hours. Then the samples are sealed so as later they can be cut on microtome. At the beginning of this procedure a sample is dehydrated by a series of retention in ethanol of different concentration, for 24 hours in each: $70 \%, 80 \%$, $96 \%, 100 \%$. Then the samples are placed into the xylolparaffin compound and then into liquid paraffin for 1-2 hours at a temperature of $52-56^{\circ} \mathrm{C}$. When paraffin solidifies, the element with the sample inside is cut off cutoff with a thickness of $5-15 \mathrm{~nm}$ is made on microtome. The cutoffs are placed on the warm water surface for their straightening and then - on slide. At the next stage the samples are released from paraffin by a series of for 2-5 minutes: xylol, ethanol 100\%, 96\%, 80\%, 70\%, 60\%. For staining slides with cutoffs are placed in trypan blue solution for a short time, washed with water, dehydrated by a series of different spirit concentrations (as stated above) and then brightened (in carbol-xylol or xylol) to remove the excessive stain. At the final stage a drop of immersion oil is added to the slide and the slide is covered with a cover glass.

Cytotoxicity is defined according to the formula:

$$
K_{c}=\left(N_{e x}-N_{c o n t} / \mathrm{N}_{t o t}\right) \cdot 100 \%,
$$

where $N_{e x}$ is the number of cells stained during the experiment, $N_{\text {cont }}$ is the number of cells stained in control, $N_{\text {tot }}$ is the total number of cells in the slide on the calculated area.

Immunomodulatory qualities of biologically active peptides are tested according to the method based on the in vitro identification of lymphocyte surface markers, using antibodies, tagged with fluorochrome, and flow cytometry. For this purpose the lymphocyte compound is defined according to the CD nomenclature, in accordance with which each molecule, regardless its chemical structure, has the certain number. The presence of molecule on surface is denoted as "+", the absence is demoted as "-_" [19].

Immunophenotyping is used for defining the immunomodulatory qualities: cells are stained with dyes, specific to $\mathrm{CD}$ antibodies conjugated with fluorescent dyes. Attachment of the marked antibodies to cell is defined by what precisely CDs it expresses. After this staining cell fluorescence is analysed using flow cytometry.

Prior to work beginning, the lysing solution is prepared (450 mkL per test tube) by its dilution in 10 times deionised water. This solution provides erythrocyte hypotonic lysis, at the same time the medium conditions remain mild enough to preserve viability of $\sim 92 \%$ of leucocytes. Falcon test tubes of the size of $12 \times 75 \mathrm{~mm}$ are prepared and marked with A and B. $20 \mathrm{mkL}$ of solution of antibodies to CD3/CD8/CD45/ CD4 are added to the test tube A, to the test tube B 20 $\mathrm{mkL}$ of solution of antibodies to CD3/CD16, CD56/ CD45/CD19 are added. $50 \mathrm{mkL}$ of blood are added, avoiding its contact with the test tube walls. The mixtures are mixed and left in the dark at room temperature for 15 minutes. Then $450 \mathrm{mkL}$ of the lysing solution are added. The mixtures are mixed and left in the dark at room temperature for 15 minutes. The samples are analysed during 24 hours after staining.

For analysis the collected events number is set on 20000 on flow cytometry. For the test tube A analysis the following channels are used: FSC - Forward Scatter, SSC - Side Scatter, FL1-H - CD3 FITC, FL2-H - CD8 PE, FL3-H - CD45 PerCP FL4-H - CD4 APC. The results are collected in charts: FSC vs SSC, CD45 PerCP vs SSC, CD3 FITC vs CD8 PE, CD8 PE vs CD4 APC. For the test tube $\mathrm{B}$ analysis the following channels are used: FSC - Forward Scatter, SSC - Side Scatter, FL1H - CD3 FITC, FL2-H - CD16,56 PE, FL3-H - CD45 PerCP, FL4-H - CD19 APC with charts FSC vs 
SSC, CD45 PerCP vs SSC, CD3 FITC vs CD16,56 PE, CD16,56 PE vs CD19 APC.

According to the study results the percentage ratio of immune cells in control and experiment is calculated and the conclusion concerning the immunomodulatory qualities of the peptide under study is made.

Immunomodulatory qualities of biologically active peptides, derived from milk proteins in vivo, were assessed by the number of cells producing antybodies (CPA) in mice spleen in relation to ram erythrocytes (RE) in A.J. Cunningham modification [9]. The experiment was conducted on mongrel Wistar rats weighing 180 $200 \mathrm{~g}$. The T-cell immunity assessment was conducted by reproduction of delayed contact hypersensitivity (DHS) to ram erythrocytes (by difference between the edematous and healthy mice ear). Ram erythrocytes in the amount of $5 \cdot 10^{8}$ were used for immunisation. Biologically active peptides were injected in the amount of $20 \mathrm{mg} / \mathrm{kg}$ during 7 days. The comparative drug was oxymethyluracil in the amount of $50 \mathrm{mg} / \mathrm{kg}$. Phagocytes functional condition was assessed by leukocytes capability of absorbing latex particles by morphological method, at study of smear stained according to the Romanovskiy-Giemsa stain. The absolute phagocytic index indicated the phagocytosis intensity on the basis of phagocytic number of the phagocytic index and the total number of leukocytes in 11 of blood.

Antioxidant qualities of biologically active peptides are tested according to the method based on the determination of the capacity to absorb oxygen radicals (Trolox-equivalent).

Biologically active peptides antioxidant activity is measured according to the method, described by Cao et al. [20]. The initial solution of $\beta$-phycoerythrin is prepared by dilution of $1 \mathrm{mg}$ of substance in $5.6 \mathrm{ml}$ of phosphate buffer $(0.2 \mathrm{M}, \mathrm{pH} 7.0)$. The initial solution is kept in refrigerator. The process solution is prepared by mixing $300 \mathrm{mkL}$ of the initial solution with $13.4 \mathrm{ml}$ of phosphate buffer immediately before use. The 2,2'Azobis(2-amidinopropane) dihydrochloride (AAPH) solution is prepared before the test beginning. For this purpose $60 \mathrm{mg}$ of AAPH are weighed and diluted in $5 \mathrm{ml}$ of phosphate buffer. The 6-hydroxy-2,5,7,8tetramethylchroman-2-carboxyic acid (Trolox) solution is prepared by dilution of $5 \mathrm{mg}$ of substance in $200 \mathrm{ml}$ of $0.2 \mathrm{M}$ phosphate buffer as the main solution $(100 \mu \mathrm{m})$. $9 \mathrm{ml}$ of phosphate buffer are mixed with $1 \mathrm{ml}$ of initial solution to get the process solution. The initial solution is kept at a temperature of $2^{\circ} \mathrm{C}$. Phosphate buffer is got by mixing $0.75 \mathrm{M}$ solutions of $\mathrm{K}_{2} \mathrm{HPO}_{4}$ and $\mathrm{NaH}_{2} \mathrm{PO}_{4}$ in 61.6: $38.9 \mathrm{v} / \mathrm{v}$. Then the mixture is mixed with distilled water in the ratio of $1: 9$ and $\mathrm{pH}$ is adjusted to 7.0. The process solution $(0.2 \mathrm{M})$ is kept at a temperature of $2^{\circ} \mathrm{C}$.

To assess the biologically active peptides antioxidant activity, $(100 \times)$ sample aliquot is diluted and control buffer is added to the reaction mixture. The degree of protection from $\beta$-phycoerythrin oxidation is assessed quantitatively by relative fluorescence measurement at $595 \mathrm{~nm}$ and $535 \mathrm{~nm}$ during the $70-$ minute period.

In this analysis the total absorption capacity of oxygen radicals (Trolox-equivalent) is directly proportional to the area under the kinetic curve from the plotted fluorescence and time relative values. To correct any deviations caused by devices, reagents or any other analysis conditions, the value of the samples under analysis was expressed with a reference to the corresponding Trolox sums and concentrations and the values were presented in Trolox-equivalents (Cao et al., 1995). All the reactions are conducted in a 48hole tablet. $20 \mathrm{mkL}$ of the corresponding sample and $160 \mathrm{mkL}$ of the process solution with $\beta$-phycoerythrin are added to each tablet hole. Immediately before the measurement beginning, $20 \mathrm{mkL}$ of AAPH are added to each hole to initiate the reaction. The tablet is closed and placed into analyser. In analysis, compound capacity to protect $\beta$-phycoerythrin from oxidation is controlled by the decay curve. Quantitative measurement was achieved by defining the pure protection zone according to the $\beta$-phycoerythrin decay curve in the presence of AAPH.

To calculate the values of absorption capacity of oxygen radicals, the following equation is used [21, 22]:

ORAC (absorption capacity of oxygen radicals $)=$

$$
=X \cdot K \cdot\left(S_{\text {sample }}-S_{\text {blank }}\right) /\left(S_{\text {trolox }}-S_{\text {blank }}\right),
$$

where $X$ is the sample volume, mkL; $K$ is the dilution coefficient; $S$ is the area under the curve corresponding with the index; sample is the sample; blank is the control.

\section{RESULTS AND DISCUSSION}

About two decades ago it became known that milk proteins are the main source of biologically active peptides. These peptides exert their specific biological influence only after release from polypeptide chain and when they are in a free state. This aspect has been studied since 1979 and numerous peptides were found and decoded [7].

In recent times the possibility of using biologically active peptides is being discussed as a part of special products and dietary supplements designed to prevent various diseases.

Nowadays, the main biotechnological methods are increasingly applied to complex objects of natural origin and complex biochemical processes. One of such processes is the polypeptide and protein polymer chain enzymic hydrolysis (proteolysis). It underlies a number of biological phenomena which are manifested in a wide range of peptide bonds hydrolysis extent from limited proteolysis with the enzymes activation to deep hydrolysis. Proteolysis has an important role in dietary proteins modification processes and in protein hydrolyzate production in food industry. To derive biologically active peptides from inactive protein precursors by proteolysis is a promising method of deriving biopeptides.

Determination and selection of the rational parameters of treatment for biological systems containing milk proteins with the aim of getting hydrolyzates is the main task, realisation of which allows to create an effective technology of deriving biologically active peptide complexes based on milk proteins.

In the present study casein was used as the initial raw material. It is an affordable and biologically 
valuable protein source, as well as most adapted to organism physiological characteristics in comparison with different proteins $[1,6]$. It is known that caseins, unlike some globular proteins, are well decayed by proteinases in a native state because they, being already in a native state, have a little-ordered confirmatio which is similar to denaturated globular proteins disorganised structure $[10,11,12]$. It is explained by very low $\alpha$-spirals content and low structural organisation of the main casein components, which is due to high proline content in these proteins - from 8.5 to $16.0 \%$, which apparently deforms it to an irregular snarl.

Casein peptide bonds enzymic hydrolysis was conducted by proteolytic enzymes: trypsin, chymotrypsin and thermolysin. The technological process of deriving biologically active peptides from milk proteins is conducted according to the scheme represented in figure 1. It includes the following operations: acceptance, quality assessment, raw materials preparation; addition of phosphates; casein dilution; bringing $\mathrm{pH}$ to 7.5 ; pasteurisation at a temperature of $74 \pm 2^{\circ} \mathrm{C}$ with retention during 15-20 seconds, aimed at destructing microorganisms contained in casein, cooling to a temperature of $37+2^{\circ} \mathrm{C}$, addition of enzymic system containing trypsin, chymotrypsin and thermolysin.

Enzymic hydrolysis is conducted under the following parameters: temperature of $37+2^{\circ} \mathrm{C}$, duration $8.00 \pm 0.05 \mathrm{~h}, \mathrm{pH} 7.5 \pm 0,1 \mathrm{~h}$, enzyme-substrate ratio of 1 to 50. To avoid the outside microbiota growth and bad smell appearance, before the fermentation process beginning $0.5 \%$ toluene is added which then evaporates completely during inactivation process. For the purpose of enzyme complex inactivation and of pathogenic microbiota removal, the obtained hydrolyzate is heated to $95 \pm 2^{\circ} \mathrm{C}$ during 30 seconds.

The next stage of the studies is to study amino acid succession in the released fragments at the chosen hydrolysis parameters. Molecular mass of the derived peptides was defined by MALDI-time-of-flight massspectrometer Reflect III (Bruker, Germany) equipped with an ultraviolet laser with the wave length of $336 \mathrm{~nm}$. 2.5-dihydroxybenzoic acid (Sigma, Germany) was used as a matrix in $20 \%$ acetonitrile, $0.1 \%$ TFA in the concentration of $10 \mathrm{mg} / \mathrm{ml}$. To determine amino acid succession of peptides the system for protein sequencing Procise cLC 491 (Applied Biosystems, USA) was used. Phenylthiohydant derivatives of amino acid residues were identified by 120A PTH analyser (Applied Biosystems, USA). The obtained results are represented in Table 1 .

Analysis of Table 1 indicates that all the tested fractions of casein trypsin, chymotrypsin and thermolysin hydrolyzates contain peptides consisting of different number of amino acid residues. Thus, in casein trypsin hydrolyzate 9 peptides were detected, consisting of 3-35 amino acid residues. In casein chymotrypsin hydrolyzate 9 peptides were detected, consisting of 1-56 amino acid residues. In casein thermolysin hydrolyzate 11 peptides were detected, consisting of 2-19 amino acid residues.
Table 1. Characterisation of peptides resulted from hydrolysis of casein by trypsin

\begin{tabular}{|c|c|c|}
\hline $\begin{array}{l}\text { Molecular } \\
\text { mass, Da }\end{array}$ & $\begin{array}{c}\text { Order in } \\
\text { polypeptide } \\
\text { chain }\end{array}$ & Amino acid succession \\
\hline \multicolumn{3}{|c|}{ Trypsin hydrolyzate } \\
\hline 3803 & $1-25$ & $\begin{array}{l}\text { RELEELNVPGEIVESLSSSE } \\
\text { ESITR }\end{array}$ \\
\hline 1131 & $26-32$ & WTAQQKEL \\
\hline 1463 & $33-48$ & FQSEEQQTEDELQDK \\
\hline 3754 & $52-86$ & $\begin{array}{l}\text { AQTQSLVYPFPGPIPNSLPQ } \\
\text { NIPPLTQTPVVVPPF }\end{array}$ \\
\hline 3668 & $87-118$ & $\begin{array}{l}\text { LQPEVMGVSKVKEAMAPKHK } \\
\text { EMPFPKYPVEPF }\end{array}$ \\
\hline 642 & $125-129$ & EIVPN \\
\hline 443 & $161-163$ & YPE \\
\hline 2209 & 184-202 & LLYEQPVLGPVGPPPIIV \\
\hline 585 & 203-209 & GPFPIIV \\
\hline \multicolumn{3}{|c|}{ Chymotrypsin hydrolyzate } \\
\hline 98 & 29 & K \\
\hline 368 & $48-50$ & GKE \\
\hline 848 & $60-66$ & YPPPGPI \\
\hline 972 & $81-88$ & SSSEEIVP \\
\hline 426 & 92-94 & KED \\
\hline 762 & $100-104$ & TGEDHN \\
\hline 5172 & $114-169$ & $\begin{array}{l}\text { YPVEPFTESQSLTLTDVENLHL } \\
\text { PLPLLQSWMHQPHQPLPPWV } \\
\text { MFPPQSVLSLSQSK }\end{array}$ \\
\hline 385 & $173-176$ & AYP \\
\hline 1717 & 190-209 & QEPVLGPVRGPFPIIV \\
\hline \multicolumn{3}{|c|}{ Thermolysin hydrolyzate } \\
\hline 1802 & $26-32$ & INKKIEKF \\
\hline 390 & $30-32$ & IEK \\
\hline 2329 & $33-51$ & QSEEQQQTEDELQDKIHPF \\
\hline 180 & 98-99 & $\mathrm{VK}$ \\
\hline 293 & $106-107$ & $\mathrm{KE}$ \\
\hline 690 & $108-113$ & EMPFPK \\
\hline 585 & $145-148$ & QQKE \\
\hline 889 & 169-175 & KVLPVPE \\
\hline 443 & 191-193 & LLY \\
\hline 616 & 195-199 & SDIPN \\
\hline 915 & $205-210$ & ENSEKTT \\
\hline
\end{tabular}

Note. A - alanine; $\mathrm{N}$ - asparagine $\mathrm{D}$ - aspartic acid; Q - glutamine; $\mathrm{E}$ - glutamine acid; $\mathrm{G}$ - glycine; $\mathrm{H}$ - histidine; $\mathrm{I}$ - isoleucine; $\mathrm{L}$ - leucine; $\mathrm{K}$ - lysin; $\mathrm{P}$ - proline; $\mathrm{S}$ - serine; $\mathrm{T}$ - threonine; $\mathrm{W}$ - tryptophan; $\mathrm{Y}$ - tyrosine; $\mathrm{V}$ - valine.

Identification of the obtained peptide successions was performed by dint of searching in the NCBI (www.ncbi.nlm.gov) and SwissProt (www.expasy. ch) databases. The results of the comparative tests are represented in Table 2.

Table 2 indicates that two biologically active peptides with immunomodulatory activity are detected in casein trypsin hydrolyzate: Trp-Tre-Ala-Glu-Glu-Lys-GluLeu and Leu-Leu-Tyr-Glu-Glu-Pro-Val-Leu-Gly-ProVal-Gly-Pro-Pro-Pro-Ile-Ile-Val. Casein chymotrypsin hydrolyzate contains three biologically active peptides with immunomodulatory (Tyr-Pro-Pro-Pro-Gly-Pro-Ile), 
antioxidant (Lys-Glu-Asn) and anti-tumour (Tre-GlyGlu-Asn-His-Asp) activity. Casein hydrolyzate, obtained under the thermolysin action, contains three biologically active peptides, two of which are immunomodulatory (Lys-Val-Leu-Pro-Val-Pro-Glu and Leu-Leu-Tyr) and one is antioxidant (Lys-Glu).

Elaboration of the method of separation and purification of biologically active peptides [13, 14], containing in casein hydrolyzates, is of interest. To derive purified biologically active peptides the following methods were implemented in the present study:

1) ultrafiltration

2) gel filtration on sephadex G-25

3) successive stages: ultrafil ration, preparative electrophoresis, reversed-phase high-performance liquid chromatography.

Assessment of biologically active peptides purity degree in all variants was conducted by the analytic protein electrophoresis, mass spectrometry MALDITOF and analytic reversed-phase high-performance liquid chromatography.

The results of purification of peptides, derived from casein trypsin, chymotrypsin and thermolysin hydrolyzates, which was conducted in different ways, are represented in tables 3-5.

Tables 3-5 indicate that the most effective purification of biologically active peptides, derived from casein enzymic hydrolyzate, is achieved by using multi-stage purification: ultrafiltration, preparative electrophoresis, reversed-phase high-performance liquid chromatography. In this case the purity degree of biologically active peptides, derived from casein trypsin hydrolyzate, is within the range of $86.7-92.4 \%$; from casein chymotrypsin hydrolyzate the degree is within the range of 88.9-95.4\%; from thermolysin hydrolyzate the degree is within the range of 85.2-97.6\%.

Based on the obtained results, the following scheme is recommended for deriving and purifying biologically active peptides from casein enzymic hydrolyzate: successive ultrafilration stages on the device MFU-R-45-300, preparative electrophoresis stages in $12.5 \%$ polyacrylamide gel in the chamber, produced by the company Bio-Rad, and reversed-phase high-performance liquid chromatography stages on chromatograph LC-20.

Due to the prospects of use of biologically active peptides, derived from milk proteins, the study of such bioactive peptides qualities as cytotoxic (anti-tumour), antioxidant, prebiotic and immunomodulatory, as one of the components of the functional foodstuffs for cancer patients rehabilitation, is of interest.

Cytotoxicity of biologically active peptides, derived from milk proteins, was studies in vitro on the following cancer cell lines: Burkitt's lymphoma LBR2, human prostate cancer DU 145, human breast cancer MDAMB-231 and MCF7, hepatocellular carcinoma HepG2, brain cancer U-87, human pancreas cancer PANC-1. The living cells number in holes after the end of the period of incubation with biologically active peptides is performed with the MTT-colorimetric assay.

Table 2. Peptides with biological activity, detected in casein hydrolyzates under study

\begin{tabular}{|c|c|c|c|}
\hline Fragment & Enzyme used & Amino acid succession in peptides & Function \\
\hline $26-32$ & Trypsin & Trp-Tre-Ala-Glu-Glu-Lys-Glu-Leu & Immunomodulatory \\
\hline $184-202$ & Trypsin & $\begin{array}{c}\text { Leu-Leu-Tyr-Glu-Glu-Pro-Val-Leu-Gly-Pro-Val-Gly- } \\
\text { Pro-Pro-Pro-Ile-Ile-Val }\end{array}$ & Immunomodulatory \\
\hline $60-66$ & Chymotrypsin & Tyr-Pro-Pro-Pro-Gly-Pro-Ile & Immunomodulatory \\
\hline $92-94$ & Chymotrypsin & Lys-Glu-Asn & Antioxidant \\
\hline $100-104$ & Chymotrypsin & Tre-Gly-Glu-Asn-His-Asp & Anti-tumour \\
\hline $106-107$ & Thermolysin & Lys-Glu & Immunomodulatory \\
\hline $169-175$ & Thermolysin & Lys-Val-Leu-Pro-Val-Pro-Glu & Immunomodulatory \\
\hline $191-193$ & Thermolysin & Leu-Leu-Tyr & \\
\hline
\end{tabular}

Table 3. Purification results of biopeptides peptides derived from casein hydrolyzates and purified with ultrafiltrat

\begin{tabular}{|c|c|c|c|}
\hline $\begin{array}{c}\text { Fraction } \\
\text { number }\end{array}$ & $\begin{array}{c}\text { Molecular mass, } \\
\text { Da }\end{array}$ & Amino acid succession & $\begin{array}{c}\text { Purity } \\
\text { degree, } \%\end{array}$ \\
\hline \multicolumn{7}{|c|}{ Trypsin hydrolyzate } \\
\hline 1 & 1131 & Trp-Tre-Ala-Glu-Glu-Lys-Glu-Leu & 45.0 \\
\hline 2 & 2209 & Leu-Leu-Tyr-Glu-Glu-Pro-Val-Leu-Gly-Pro-Val-Gly-Pro-Pro-Pro-Ile-Ile-Val & 52.5 \\
\hline \multicolumn{7}{|c|}{ Chymotrypsin hydrolyzate } & 48.7 \\
\hline 1 & 848 & Tyr-Pro-Pro-Pro-Gly-Pro-Ile & 43.9 \\
\hline 2 & 426 & Tre-Gly-Glu-Asn-His-Asp & 44.6 \\
\hline 3 & 762 & Thermolysin hydrolyzate & 38.5 \\
\hline \multicolumn{7}{|c|}{ Lys-Glu } & 47.2 \\
\hline 1 & 293 & Lys-Val-Leu-Pro-Val-Pro-Glu & 44.1 \\
\hline 3 & 889 & Leu-Leu-Tyr & \\
\hline
\end{tabular}


Table 4. Purification results of biopeptides peptides derived from casein hydrolyzates and purified with gel filtration on sephadex G-25

\begin{tabular}{|c|c|c|c|}
\hline $\begin{array}{c}\text { Fraction } \\
\text { number }\end{array}$ & $\begin{array}{c}\text { Molecular mass, } \\
\text { Da }\end{array}$ & Amino acid succession & $\begin{array}{c}\text { Purity } \\
\text { degree, } \%\end{array}$ \\
\hline \multicolumn{7}{|c|}{ Trypsin hydrolyzate } & 56.8 \\
\hline 1 & 1131 & Trp-Tre-Ala-Glu-Glu-Lys-Glu-Leu & 64.5 \\
\hline 2 & 2209 & Leu-Leu-Tyr-Glu-Glu-Pro-Val-Leu-Gly-Pro-Val-Gly-Pro-Pro-Pro-Ile-Ile-Val & 55.0 \\
\hline \multicolumn{7}{|c|}{ Chymotrypsin hydrolyzate } & 58.9 \\
\hline 1 & 848 & Tyr-Pro-Pro-Pro-Gly-Pro-Ile & 60.2 \\
\hline 2 & 426 & Tre-Gly-Glu-Asn-His-Asp & 49.3 \\
\hline 3 & 762 & Thermolysin hydrolyzate & 62.1 \\
\hline \multicolumn{7}{|c|}{ L Lys-Glu } \\
\hline 1 & 293 & Lys-Val-Leu-Pro-Val-Pro-Glu & 58.0 \\
\hline 2 & 889 & Leu-Leu-Tyr & \\
\hline 3 & 443 &
\end{tabular}

Table 5. Purification results of biopeptides peptides derived from casein hydrolyzates and purified with a combination of ultrafiltration, preparative electrophoresis and reversed-phase high-performance liquid chromatograph

\begin{tabular}{|c|c|c|c|}
\hline $\begin{array}{l}\text { Fraction } \\
\text { number }\end{array}$ & $\begin{array}{c}\text { Molecular mass, } \\
\mathrm{Da}\end{array}$ & Amino acid succession & $\begin{array}{c}\text { Purity } \\
\text { degree, \% }\end{array}$ \\
\hline \multicolumn{4}{|c|}{ Trypsin hydrolyzate } \\
\hline 1 & 1131 & Trp-Tre-Ala-Glu-Glu-Lys-Glu-Leu & 86.7 \\
\hline 2 & 2209 & Leu-Leu-Tyr-Glu-Glu-Pro-Val-Leu-Gly-Pro-Val-Gly-Pro-Pro-Pro-Ile-Ile-Val & 92.4 \\
\hline \multicolumn{4}{|c|}{ Chymotrypsin hydrolyzate } \\
\hline 1 & 848 & Tyr-Pro-Pro-Pro-Gly-Pro-Ile & 88.9 \\
\hline 2 & 426 & Lys-Glu-Asn & 95.4 \\
\hline 3 & 762 & Tre-Gly-Glu-Asn-His-Asp & 92.3 \\
\hline \multicolumn{4}{|c|}{ Thermolysin hydrolyzate } \\
\hline 1 & 293 & Lys-Glu & 85.2 \\
\hline 2 & 889 & Lys-Val-Leu-Pro-Val-Pro-Glu & 97.6 \\
\hline 3 & 443 & Leu-Leu-Tyr & 94.1 \\
\hline
\end{tabular}

The results of the study of cytotoxicity of biologically active peptides, derived from milk proteins, are represented in Table 6 .

The data of Table 6 indicate that all peptides under study have cytotoxic qualities, at the same time increase in biopeptide concentration causes decrease in the capacity for survival of cancer cells of different lines. Biologically active peptide with the composition TrpTre-Ala-Glu-Glu-Lys-Glu-Leu, derived from trypsin hydrolyzate, is characterised by the most pronounced cytotoxic activity in relation to MCF7 cell line (cancer cells survival rate at the peptide concentration of 0.1 mas. $\%$ is $38.7 \%$ ), $6 \mathrm{HepG} 2$ cell line (cancer cells survival rate at the peptide concentration of 0.1 mas. $\%$ is $32.4 \%$ ) and PANC-1 cell line (cancer cells survival rate at the peptide concentration of 0.1 mas. $\%$ is $26.5 \%$ ). Biologically active peptide with the composition LeuLeu-Tyr-Glu-Glu-Pro-Val-Leu-Gly-Pro-Val-Gly-

Pro-Pro-Pro-Ile-Ile-Val, derived from trypsin hydrolyzate, is characterised by the most pronounced cytotoxic activity in relation to DU 145 cell line (cancer cells survival rate at the peptide concentration of 0.1 mas. $\%$ is $30.3 \%$ ), MDAMB-231 cell line (cancer cells survival rate at the peptide concentration of 0.1 mas. $\%$ is $27.2 \%$ ) and $6 \mathrm{HepG} 2$ cell line (cancer cells survival rate at the peptide concentration of 0.1 mas. $\%$ is $29.8 \%$ ).
Biologically active peptide with the composition TyrPro-Pro-Pro-Gly-Pro-Ile, derived from chymotrypsin hydrolyzate, is characterised by the most pronounced cytotoxic activity in relation to LBR2 cell line (cancer cells survival rate at the peptide concentration of 0.1 mas. $\%$ is $33.1 \%$ ), MDAMB-231 cell line (cancer cells survival rate at the peptide concentration of 0.1 mas. $\%$ is $31.0 \%$ ), 6 HepG2 cell line (cancer cells survival rate at the peptide concentration of 0.1 mas.\% is $26.6 \%$ ) and PANC-1 cell line (cancer cells survival rate at the peptide concentration of 0.1 mas. $\%$ is $28.6 \%$ ).

Biologically active peptide with the composition Leu-Leu-Tyr, derived from thermolysin hydrolyzate, is characterised by the most pronounced cytotoxic activity in relation to LBR2 cell line (cancer cells survival rate at the peptide concentration of 0.1 mas. $\%$ is $31.3 \%$ ), DU 145 cell line (cancer cells survival rate at the peptide concentration of 0.1 mas. $\%$ is $29.0 \%$ ) and MDAMB-231 cell line (cancer cells survival rate at the peptide concentration of 0.1 mas. $\%$ is $30.5 \%$ ).

Antioxidant qualities of biologically active peptides, derived from milk proteins, were analysed according to the method based on the determination of the capacity to absorb oxygen radicals (Trolox-equivalent). The results of the study of antioxidant qualities of biologically active peptides, derived from milk proteins, are represented in Fig. 1. 
Table 6. Results of the study of cytotoxicity of biologically active peptides derived from milk proteins

\begin{tabular}{|c|c|c|c|c|c|c|c|}
\hline \multirow{2}{*}{$\begin{array}{l}\text { Biologically active peptide with } \\
\text { different concentration, mas. } \%\end{array}$} & \multicolumn{7}{|c|}{ Cells survival rate, $\%$ for different cell lines } \\
\hline & LBR2 & DU 145 & MDAMB-231 & MCF7 & 6HepG2 & $\mathrm{U}-87$ & PANC-1 \\
\hline \multicolumn{8}{|c|}{ Trypsin hydrolyzate } \\
\hline $\begin{array}{l}\text { Trp-Tre-Ala-Glu-Glu-Lys-Glu-Leu } \\
0.005 \\
0.010 \\
0.100\end{array}$ & $\begin{array}{l}91.7 \pm 4.6 \\
80.3 \pm 4.0 \\
66.7 \pm 3.3\end{array}$ & $\begin{array}{l}88.0 \pm 4.4 \\
75.4 \pm 3.8 \\
62.3 \pm 3.1\end{array}$ & $\begin{array}{l}83.4 \pm 4.2 \\
72.0 \pm 3.6 \\
60.2 \pm 3.0\end{array}$ & $\begin{array}{l}89.6 \pm 4.5 \\
61.3 \pm 3.1 \\
38.7 \pm 1.9\end{array}$ & $\begin{array}{l}77.6 \pm 3.9 \\
49.9 \pm 2.5 \\
32.4 \pm 1.6\end{array}$ & $\begin{array}{l}90.4 \pm 4.5 \\
65.5 \pm 3.3 \\
58.9 \pm 2.9\end{array}$ & $\begin{array}{l}74.0 \pm 3.7 \\
43.2 \pm 2.2 \\
26.5 \pm 1.3\end{array}$ \\
\hline $\begin{array}{l}\text { Leu-Leu-Tyr-Glu-Glu-Pro-Val- } \\
\text { Leu-Gly-Pro-Val-Gly-Pro-Pro-Pro- } \\
\text { Ile-Ile-Val } \\
0.005 \\
0.010 \\
0.100\end{array}$ & $\begin{array}{l}87.8 \pm 4.4 \\
70.3 \pm 3.5 \\
56.2 \pm 2.8\end{array}$ & $\begin{array}{l}76.0 \pm 3.8 \\
46.5 \pm 2.3 \\
30.3 \pm 1.5\end{array}$ & $\begin{array}{l}79.5 \pm 4.0 \\
41.1 \pm 2.0 \\
27.2 \pm 1.4 \\
\end{array}$ & $\begin{array}{l}95.6 \pm 4.8 \\
81.3 \pm 4.1 \\
64.0 \pm 3.2 \\
\end{array}$ & $\begin{array}{l}79.4 \pm 4.0 \\
47.0 \pm 2.3 \\
29.8 \pm 1.5\end{array}$ & $\begin{array}{l}89.0 \pm 4.4 \\
77.5 \pm 3.9 \\
55.3 \pm 2.8\end{array}$ & $\begin{array}{l}92.9 \pm 4.6 \\
81.1 \pm 4.0 \\
60.4 \pm 3.0\end{array}$ \\
\hline \multicolumn{8}{|c|}{ Chymotrypsin hydrolyzate } \\
\hline $\begin{array}{l}\text { Tyr-Pro-Pro-Pro-Gly-Pro-Ile } \\
0.005 \\
0.010 \\
0.100\end{array}$ & $\begin{array}{l}83.4 \pm 4.2 \\
50.2 \pm 2.5 \\
33.1 \pm 1.7\end{array}$ & $\begin{array}{l}94.0 \pm 4.7 \\
76.5 \pm 3.8 \\
53.0 \pm 2.7\end{array}$ & $\begin{array}{l}79.9 \pm 4.0 \\
48.7 \pm 2.4 \\
31.0 \pm 2.0 \\
\end{array}$ & $\begin{array}{l}92.1 \pm 4.6 \\
79.0 \pm 4.0 \\
57.6 \pm 2.9\end{array}$ & $\begin{array}{l}75.5 \pm 3.8 \\
44.2 \pm 2.2 \\
26.6 \pm 1.3\end{array}$ & $\begin{array}{l}93.7 \pm 4.7 \\
68.0 \pm 3.4 \\
55.2 \pm 2.8\end{array}$ & $\begin{array}{l}80.4 \pm 4.0 \\
47.8 \pm 2.4 \\
28.6 \pm 1.4\end{array}$ \\
\hline $\begin{array}{l}\text { Lys-Glu-Asn } \\
0.005 \\
0.010 \\
0.100\end{array}$ & $\begin{array}{l}92.0 \pm 4.6 \\
69.4 \pm 3.5 \\
47.8 \pm 2.4\end{array}$ & $\begin{array}{l}81.2 \pm 4.1 \\
52.3 \pm 2.6 \\
32.5 \pm 1.6\end{array}$ & $\begin{array}{l}95.6 \pm 4.8 \\
75.4 \pm 3.8 \\
52.0 \pm 2.6\end{array}$ & $\begin{array}{l}77.6 \pm 3.9 \\
47.4 \pm 2.4 \\
29.4 \pm 1.5\end{array}$ & $\begin{array}{l}79.0 \pm 4.0 \\
53.5 \pm 2.7 \\
30.2 \pm 1.5\end{array}$ & $\begin{array}{l}94.0 \pm 4.7 \\
74.3 \pm 3.7 \\
51.5 \pm 2.6\end{array}$ & $\begin{array}{l}92.0 \pm 4.6 \\
71.2 \pm 3.6 \\
49.9 \pm 2.5\end{array}$ \\
\hline $\begin{array}{l}\text { Tre-Gly-Glu-Asn-His-Asp } \\
0.005 \\
0.010 \\
0.100\end{array}$ & $\begin{array}{l}85.3 \pm 4.3 \\
67.0 \pm 3.3 \\
43.2 \pm 2.2\end{array}$ & $\begin{array}{l}88.2 \pm 4.4 \\
62.0 \pm 3.1 \\
41.2 \pm 2.1\end{array}$ & $\begin{array}{l}70.0 \pm 3.5 \\
45.5 \pm 2.3 \\
28.8 \pm 1.4\end{array}$ & $\begin{array}{l}96.5 \pm 4.8 \\
79.0 \pm 4.0 \\
66.3 \pm 3.3\end{array}$ & $\begin{array}{l}69.8 \pm 3.5 \\
42.0 \pm 2.1 \\
25.6 \pm 1.3\end{array}$ & $\begin{array}{l}75.5 \pm 3.8 \\
48.9 \pm 2.4 \\
29.0 \pm 1.4\end{array}$ & $\begin{array}{l}87.6 \pm 4.4 \\
65.0 \pm 3.2 \\
44.2 \pm 2.2\end{array}$ \\
\hline \multicolumn{8}{|c|}{ Thermolysin hydrolyzate } \\
\hline $\begin{array}{l}\text { Lys-Glu } \\
0.005 \\
0.010 \\
0.100\end{array}$ & $\begin{array}{l}78.6 \pm 3.9 \\
49.0 \pm 2.4 \\
30.7 \pm 1.5\end{array}$ & $\begin{array}{l}92.1 \pm 4.6 \\
77.6 \pm 3.9 \\
48.0 \pm 2.4\end{array}$ & $\begin{array}{l}76.9 \pm 3.8 \\
47.0 \pm 2.3 \\
29.5 \pm 1.5\end{array}$ & $\begin{array}{l}90.0 \pm 4.5 \\
78.3 \pm 3.9 \\
51.1 \pm 2.6\end{array}$ & $\begin{array}{l}87.5 \pm 4.4 \\
71.1 \pm 3.6 \\
48.7 \pm 2.4\end{array}$ & $\begin{array}{l}75.5 \pm 3.8 \\
46.2 \pm 2.3 \\
28.8 \pm 1.4\end{array}$ & $\begin{array}{l}88.4 \pm 4.4 \\
75.0 \pm 3.8 \\
49.9 \pm 2.5\end{array}$ \\
\hline $\begin{array}{l}\text { Lys-Val-Leu-Pro-Val-Pro-Glu } \\
0.005 \\
0.010 \\
0.100\end{array}$ & $\begin{array}{l}89.5 \pm 4.5 \\
71.5 \pm 3.6 \\
53.2 \pm 2.7\end{array}$ & $\begin{array}{l}77.0 \pm 3.9 \\
45.3 \pm 2.3 \\
27.5 \pm 1.4\end{array}$ & $\begin{array}{l}79.4 \pm 4.0 \\
46.7 \pm 2.3 \\
31.2 \pm 1.6\end{array}$ & $\begin{array}{l}92.0 \pm 4.6 \\
77.4 \pm 3.9 \\
54.6 \pm 2.7\end{array}$ & $\begin{array}{l}81.2 \pm 4.1 \\
53.4 \pm 2.7 \\
30.8 \pm 1.5\end{array}$ & $\begin{array}{l}94.6 \pm 4.7 \\
75.4 \pm 3.8 \\
48.9 \pm 2.4\end{array}$ & $\begin{array}{l}95.0 \pm 4.8 \\
73.2 \pm 3.7 \\
46.5 \pm 2.3\end{array}$ \\
\hline $\begin{array}{l}\text { Leu-Leu-Tyr } \\
0.005 \\
0.010 \\
0.100\end{array}$ & $\begin{array}{l}78.5 \pm 3.9 \\
44.2 \pm 2.2 \\
31.3 \pm 1.6\end{array}$ & $\begin{array}{l}76.0 \pm 3.8 \\
45.2 \pm 2.3 \\
29.0 \pm 1.4\end{array}$ & $\begin{array}{l}79.6 \pm 4.0 \\
47.8 \pm 2.4 \\
30.5 \pm 1.5\end{array}$ & $\begin{array}{l}92.4 \pm 4.6 \\
78.0 \pm 3.9 \\
55.3 \pm 2.8\end{array}$ & $\begin{array}{l}95.0 \pm 4.8 \\
72.6 \pm 3.6 \\
53.1 \pm 2.7\end{array}$ & $\begin{array}{l}93.4 \pm 4.7 \\
74.0 \pm 3.7 \\
48.9 \pm 2.4\end{array}$ & $\begin{array}{l}90.7 \pm 4.5 \\
72.6 \pm 3.6 \\
50.3 \pm 2.5\end{array}$ \\
\hline
\end{tabular}

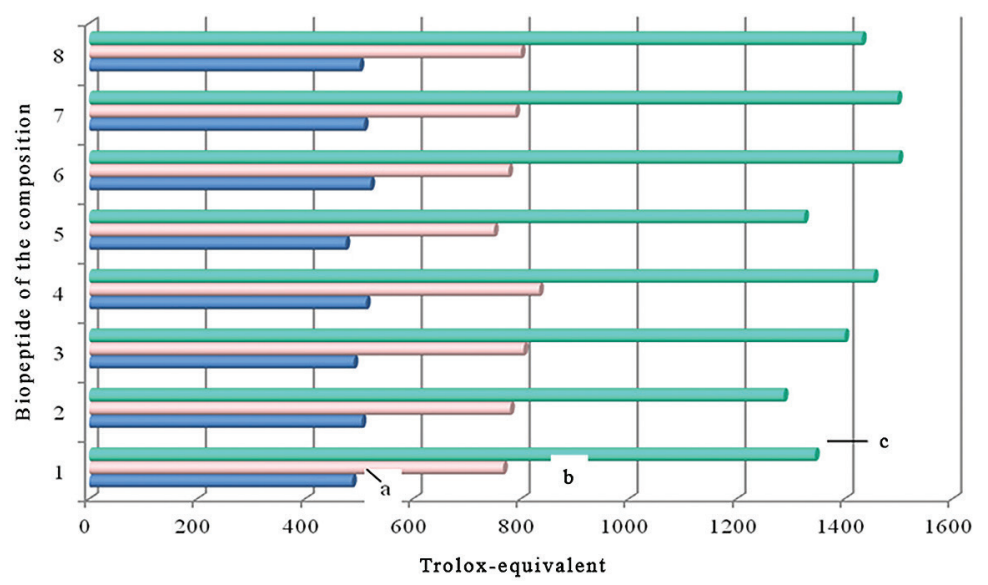

Fig. 1. Results of determination of biologically active peptides antioxidant activity: 1 - peptide with the composition Trp-Tre-Ala-Glu-Glu-Lys-Glu-Leu, 2 - peptide with the composition Leu-Leu-Tyr-Glu-Glu-Pro-Val-Leu-Gly-ProVal-Gly-Pro-Pro-Pro-Ile-Ile-Val, 3 - peptide with the composition Tyr-Pro-Pro-Pro-Gly-Pro-Ile, 4 - peptide with the composition Lys-Glu-Asn, 5 - peptide with the composition Tre-Gly-Glu-Asn-His-Asp, 6 - peptide with the composition Lys-Glu, 7 - peptide with the composition Lys-Val-Leu-Pro-Val-Pro-Glu, 8 - peptide with the composition Leu-Leu-Tyr, $\mathrm{a}$ - biopeptide concentration is 0.005 mas. $\%, \mathrm{~b}$ - biopeptide concentration is 0.010 mas. $\%$, c - biopeptide concentration is 0.100 mas. $\%$. 
Fig. 1. indicates that all the considered peptides, derived from casein trypsin, chymotrypsin and thermolysin hydrolyzates, are characterised by the pronounced antioxidant qualities: the trolox-equivalent value for biopeptide with the composition Trp-Tre-AlaGlu-Glu-Lys-Glu-Leu is within the range of 487-1345; for biopeptide with the composition Leu-Leu-Tyr-GluGlu-Pro-Val-Leu-Gly-Pro-Val-Gly-Pro-Pro-Pro-IleIle-Val the value is within the range of 505-1287; for biopeptide with the composition Tyr-Pro-Pro-Pro-GlyPro-Ile the value is within the range of 490-1400; for biopeptide with the composition Lys-Glu-Asn the value is within the range of 513-1454; for biopeptide with the composition Tre-Gly-Glu-Asn-His-Asp the value is within the range of 475-1325; for biopeptide with the composition Lys-Glu the value is within the range of 521-1500; for biopeptide with the composition LysVal-Leu-Pro-Val-Pro-Glu the value is within the range of 509-1498; for biopeptide with the composition LeuLeu-Tyr the value is within the range of 501-1432.

Prebiotic qualities of biologically active peptides, derived from milk proteins, were analysed in accordance with the Batch Culture Fermentation method in vitro (bacteria fermentation in one cycle). Results of the determination of biologically active peptides prebiotic activity are represented in Fig. 2 and 3.

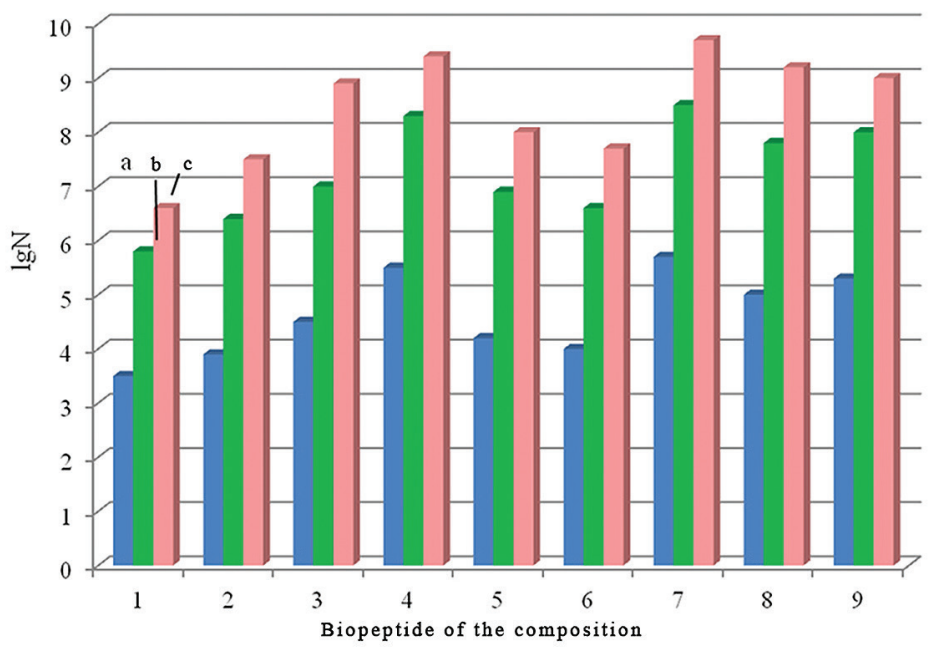

Fig. 2. Chart of change in number of bifidobacteria cells $(\operatorname{lgN})$ in nutrient medium after 4,8 and 24 hours of fermentation: 1 - control (without biopeptides), 2 - with biopeptide of the composition Trp-Tre-Ala-Glu-Glu-Lys-GluLeu, 3 - with biopeptide of the composition Leu-Leu-Tyr-Glu-Glu-Pro-Val-Leu-Gly-Pro-Val-Gly-Pro-Pro-Pro-IleIle-Val, 4 - with biopeptide of the composition Tyr-Pro-Pro-Pro-Gly-Pro-Ile, 5 - with biopeptide of the composition Lys-Glu-Asn, 6 - with biopeptide of the composition Tre-Gly-Glu-Asn-His-Asp, 7 - with biopeptide of the composition Lys-Glu, 8 - with biopeptide of the composition Lys-Val-Leu-Pro-Val-Pro-Glu, 9 - with biopeptide of the composition Leu-Leu-Tyr; a - fermentation duration is $4 \mathrm{~h}, \mathrm{~b}$ - fermentation duration is $8 \mathrm{~h}, \mathrm{c}$ - fermentation duration is $24 \mathrm{~h}$.

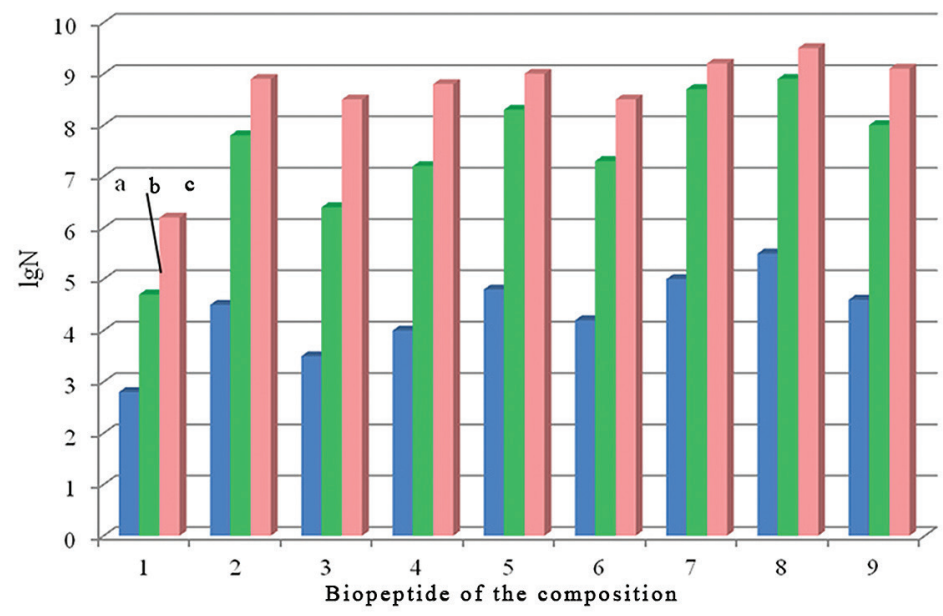

Fig. 3. Chart of change in number of lactobacilli cells $(\operatorname{lgN})$ in nutrient medium after 4,8 and 24 hours of fermentation: 1 - control (without biopeptides), 2 - with biopeptide of the composition Trp-Tre-Ala-Glu-Glu-Lys-GluLeu, 3 -with biopeptide of the composition Leu-Leu-Tyr-Glu-Glu-Pro-Val-Leu-Gly-Pro-Val-Gly-Pro-Pro-Pro-Ile-IleVal, 4 - with biopeptide of the composition Tyr-Pro-Pro-Pro-Gly-Pro-Ile, 5 - with biopeptide of the composition LysGlu-Asn, 6 - with biopeptide of the composition Tre-Gly-Glu-Asn-His-Asp, 7 - with biopeptide of the composition Lys-Glu, 8 - with biopeptide of the composition Lys-Val-Leu-Pro-Val-Pro-Glu, 9 - with biopeptide of the composition LeuLeu-Tyr; a - fermentation duration is $4 \mathrm{~h}, \mathrm{~b}$ - fermentation duration is $8 \mathrm{~h}, \mathrm{c}$ - fermentation duration is $24 \mathrm{~h}$. 
The analysis of the obtained results proved that the number of bifidobacteria and lactobacilli increases sharply when the biopeptides under analysis are present during fermentation. Peptides of the composition LysGlu, Lys-Glu-Asn and Lys-Val-Leu-Pro-Val-Pro-Glu have the greatest impact on bifidobacteria growth, peptides of the composition Lys-Val-Leu-Pro-Val-ProGlu, Lys-Glu and Leu-Leu-Tyr have the greatest impact on lactobacilli growth.

Prebiotic index was calculated for each peptide under study. The obtained results are represented in Table 7 .

Table 7 demonstrates that prebiotic index value for biologically active peptides under study which were derived from milk proteins varies within the range of 0.95-1.75, consequently, all peptides showed prebiotic influence on gastrointestinal tract microbiota. But such biopeptides as Lys-Glu (PI = 1.75), Leu-Leu-Tyr $(\mathrm{PI}=1.62)$ and Lys-Val-Leu-Pro-Val-Pro-Glu $(\mathrm{PI}=1.56)$ have the most pronounced prebiotic qualities.
Table 7. Prebiotic index of biologically active peptides derived from milk proteins

\begin{tabular}{|l|c|}
\hline \multicolumn{1}{|c|}{ Peptide of the composition } & PI \\
\hline Trp-Tre-Ala-Glu-Glu-Lys-Glu-Leu & 0.99 \\
\hline $\begin{array}{l}\text { Leu-Leu-Tyr-Glu-Glu-Pro-Val-Leu-Gly-Pro- } \\
\text { Val-Gly-Pro-Pro-Pro-Ile-Ile-Val }\end{array}$ & 1.05 \\
\hline Tyr-Pro-Pro-Pro-Gly-Pro-Ile & 1.21 \\
\hline Lys-Glu-Asn & 1.13 \\
\hline Tre-Gly-Glu-Asn-His-Asp & 0.95 \\
\hline Lys-Glu & 1.75 \\
\hline Lys-Val-Leu-Pro-Val-Pro-Glu & 1.56 \\
\hline Leu-Leu-Tyr & 1.62 \\
\hline
\end{tabular}

Results of the assessment of biologically active peptides influence on the immune humoral response are represented in Table 3, on phagocytosis - in Table 8.

Table 9 indicates that all the considered biologically active peptides, derived from milk proteins, increase

Table 8. Influence of biologically active peptides, derived from milk proteins, on immune humoral response (cells producing antibodies formation in mice spleen and delayed hypersensitivity to ram erythrocytes)

\begin{tabular}{|l|c|c|c|c|}
\hline \multicolumn{1}{|c|}{ Peptide } & $\begin{array}{c}\text { Dose, } \\
\mathrm{mg} / \mathrm{kg}\end{array}$ & $\begin{array}{c}\text { DHS to ram } \\
\text { erythrocytes }\end{array}$ & $\begin{array}{c}\text { CPA number } \\
\text { in the whole spleen }\end{array}$ & $\begin{array}{c}\text { CPA number } \\
\text { on 1 m splenocytes }\end{array}$ \\
\hline Trp-Tre-Ala-Glu-Glu-Lys-Glu-Leu & 20.0 & $28.7 \pm 4.3$ & $36788 \pm 6622$ & $365.1 \pm 54.8$ \\
\hline $\begin{array}{l}\text { Leu-Leu-Tyr-Glu-Glu-Pro-Val-Leu-Gly-Pro- } \\
\text { Val-Gly-Pro-Pro-Pro-Ile-Ile-Val }\end{array}$ & 20.0 & $32.4 \pm 4.9$ & $37023 \pm 6664$ & $372.0 \pm 55.8$ \\
\hline Tyr-Pro-Pro-Pro-Gly-Pro-Ile & 20.0 & $30.6 \pm 4.6$ & $38546 \pm 6938$ & $375.3 \pm 56.3$ \\
\hline Lys-Glu-Asn & 20.0 & $31.8 \pm 4.8$ & $36400 \pm 6552$ & $357.0 \pm 53.6$ \\
\hline Tre-Gly-Glu-Asn-His-Asp & 20.0 & $29.4 \pm 4.4$ & $36777 \pm 6620$ & $362.7 \pm 54.4$ \\
\hline Lys-Glu & 20.0 & $33.0 \pm 5.0$ & $37145 \pm 6686$ & $373.1 \pm 56.0$ \\
\hline Lys-Val-Leu-Pro-Val-Pro-Glu & 20.0 & $31.6 \pm 4.7$ & $38241 \pm 6883$ & $374.0 \pm 56.1$ \\
\hline Leu-Leu-Tyr & 20.0 & $32.9 \pm 4.9$ & $36315 \pm 6537$ & $354.2 \pm 53.1$ \\
\hline Oxymethyluracil & 50.0 & $31.4 \pm 4.7$ & $85205 \pm 6816$ & $462.5 \pm 92.5$ \\
\hline Control & - & $46.5 \pm 7.0$ & $28955 \pm 7239$ & $195.6 \pm 35.2$ \\
\hline
\end{tabular}

Table 9. Influence of biologically active peptides, derived from milk proteins, on phagocytosi

\begin{tabular}{|c|c|c|c|c|c|}
\hline Peptide & $\begin{array}{l}\text { Dose, } \\
\mathrm{mg} / \mathrm{kg}\end{array}$ & $\begin{array}{c}\text { Time, } \\
\text { day }\end{array}$ & $\begin{array}{l}\text { Phagocytic } \\
\text { number, \% }\end{array}$ & $\begin{array}{l}\text { Phagocytic } \\
\text { index }\end{array}$ & $\begin{array}{c}\text { Absolute } \\
\text { phagocytic index }\end{array}$ \\
\hline Trp-Tre-Ala-Glu-Glu-Lys-Glu-Leu & 20.0 & $\begin{array}{c}8 \\
16\end{array}$ & $\begin{array}{l}1.95 \pm 0.29 \\
5.43 \pm 0.81\end{array}$ & $\begin{array}{l}2.24 \pm 0.24 \\
2.16 \pm 0.32\end{array}$ & $\begin{array}{l}5.10 \pm 0.97 \\
1.95 \pm 0.20\end{array}$ \\
\hline $\begin{array}{l}\text { Leu-Leu-Tyr-Glu-Glu-Pro-Val-Leu-Gly-Pro- } \\
\text { Val-Gly-Pro-Pro-Pro-Ile-Ile-Val }\end{array}$ & 20.0 & $\begin{array}{c}8 \\
16\end{array}$ & $\begin{array}{l}1.88 \pm 0.28 \\
5.55 \pm 0.83\end{array}$ & $\begin{array}{l}2.20 \pm 0.33 \\
2.11 \pm 0.32\end{array}$ & $\begin{array}{l}5.17 \pm 1.03 \\
2.04 \pm 0.41\end{array}$ \\
\hline Tyr-Pro-Pro-Pro-Gly-Pro-Ile & 20.0 & $\begin{array}{c}8 \\
16\end{array}$ & $\begin{array}{l}1.90 \pm 0.29 \\
5.38 \pm 0.81\end{array}$ & $\begin{array}{l}2.22 \pm 0.33 \\
2.14 \pm 0.32\end{array}$ & $\begin{array}{l}5.33 \pm 1.07 \\
2.10 \pm 0.42\end{array}$ \\
\hline Lys-Glu-Asn & 20.0 & $\begin{array}{c}8 \\
16\end{array}$ & $\begin{array}{l}2.01 \pm 0.30 \\
5.40 \pm 0.81\end{array}$ & $\begin{array}{l}2.25 \pm 0.34 \\
2.15 \pm 0.32\end{array}$ & $\begin{array}{l}5.22 \pm 1.04 \\
1.90 \pm 0.38\end{array}$ \\
\hline Tre-Gly-Glu-Asn-His-Asp & 20.0 & $\begin{array}{c}8 \\
16 \\
\end{array}$ & $\begin{array}{l}1.98 \pm 0.30 \\
5.49 \pm 0.82\end{array}$ & $\begin{array}{l}2.18 \pm 0.33 \\
2.13 \pm 0.32\end{array}$ & $\begin{array}{l}5.25 \pm 1.05 \\
2.07 \pm 0.41\end{array}$ \\
\hline Lys-Glu & 20.0 & $\begin{array}{c}8 \\
16\end{array}$ & $\begin{array}{l}1.85 \pm 0.28 \\
5.45 \pm 0.82\end{array}$ & $\begin{array}{l}2.19 \pm 0.33 \\
2.09 \pm 0.31\end{array}$ & $\begin{array}{l}5.40 \pm 1.08 \\
2.15 \pm 0.43\end{array}$ \\
\hline Lys-Val-Leu-Pro-Val-Pro-Glu & 20.0 & $\begin{array}{c}8 \\
16 \\
\end{array}$ & $\begin{array}{l}1.92 \pm 0.29 \\
5.51 \pm 0.83\end{array}$ & $\begin{array}{l}2.20 \pm 0.33 \\
2.12 \pm 0.32\end{array}$ & $\begin{array}{l}5.36 \pm 1.07 \\
1.99 \pm 0.40\end{array}$ \\
\hline Leu-Leu-Tyr & 20.0 & $\begin{array}{c}8 \\
16\end{array}$ & $\begin{array}{l}2.05 \pm 0.31 \\
5.47 \pm 0.82\end{array}$ & $\begin{array}{l}2.23 \pm 0.33 \\
2.11 \pm 0.32\end{array}$ & $\begin{array}{l}5.30 \pm 1.06 \\
2.08 \pm 0.42\end{array}$ \\
\hline Oxymethyluracil & 50.0 & $\begin{array}{c}8 \\
16\end{array}$ & $\begin{array}{l}3.25 \pm 0.52 \\
4.05 \pm 0.65\end{array}$ & $\begin{array}{l}2.22 \pm 0.22 \\
2.67 \pm 0.53\end{array}$ & $\begin{array}{l}7.01 \pm 1.05 \\
3.25 \pm 0.65\end{array}$ \\
\hline Control & - & $\begin{array}{c}8 \\
16\end{array}$ & $\begin{array}{l}1.25 \pm 0.43 \\
2.85 \pm 0.40\end{array}$ & $\begin{array}{l}4.02 \pm 0.68 \\
3.58 \pm 0.26\end{array}$ & $\begin{array}{l}3.62 \pm 0.90 \\
1.33 \pm 0.23\end{array}$ \\
\hline
\end{tabular}


the number of cells producing antibodies in rat spleen by $1.25-1.33$ times in comparison with control. In equivalent to $1 \mathrm{~m}$ splenocytes biologically active peptides under study stimulate antibody production. Besides, the data of tables 2 and 3 indicate that biologically active peptides, derived from milk proteins, weaken delayed hypersensitivity to ram erythrocytes, which can be explained by the presence of anti-inflammatory effect in peptides under study.

In addition to immune reactions activation, inhibition of some immunologic indexes is observed at different liver lesions (phagocytes functional activity reduction, T-lymphocytes number decrease). The absolute phagocytic index is the most informative in the phagocytic activity assessment. During 16 days, after the laboratory animals have been injected with biologically active peptides, derived from milk proteins, increase in phagocytosed cells number (4.05-5.55) was observed in comparison with control $(2.85 \%)$. The average number of particles, absorbed by one cell (phagocytic index) of animals, treated with peptides under study, indicated the phagocytic activity. It was the same as phagocytic index of animals treated with oxymethyluracil (2.13 and 2.67 respectively). Based on the absolute phagocytic index analysis, it was found that all the considered biologically active peptides, derived from milk proteins, have the capacity of stimulating phagocytosis.

Thus, as a result of the conducted studies, conditions for enzymic hydrolysis of milk proteins are optimised, which provide the possibility of deriving biologically active directional peptides and of studying biologically active peptides qualities: immunomodulatory, cytotoxic, antioxidant and prebiotic.

\section{CONCLUSION}

1. Conditions for enzymic hydrolysis of milk proteins are optimised, which provide deriving biologically active directional peptides. It is found that for conduction of hydrolysis with a high level of protein decay (85-98\%) but low yield of soluble nitrogenous substances (26-30\%) the most specific enzymes are trypsin and chymotrypsin and for conduction of hydrolysis with a medium level of protein decay (52\%) and high yield of soluble nitrogenous substances (65\%) thermolysin is the most specific substance. The optimal parameters of hydrolysis conduction are chosen, which provide the polypeptide chain division into peptides and free amino acids, as well as enzymic system was chosen, consisting of chymotrypsin or thermolysin at a temperature of $37 \pm 2{ }^{\circ} \mathrm{C}$, in the enzyme-substrate ratio of 1 to 50 and process time of $12.00 \pm 0.05 \mathrm{~h}$.

2. Amino acid successions are studied in the released fragments at the set hydrolysis parameters. It was demonstrated that all the tested fractions of casein trypsin, chymotrypsin and thermolysin hydrolyzates contain peptides consisting of different number of amino acid residues.

Two biologically active peptides with immunomodulatory activity are detected in casein trypsin hydrolyzate: Trp-Tre-Ala-Glu-Glu-Lys-GluLeu and Leu-Leu-Tyr-Glu-Glu-Pro-Val-Leu-Gly-Pro-
Val-Gly-Pro-Pro-Pro-Ile-Ile-Val. Casein chymotrypsin hydrolyzate contains three biologically active peptides with immunomodulatory (Tyr-Pro-Pro-Pro-Gly-ProIle), antioxidant (Lys-Glu-Asn) and anti-tumor (TreGly-Glu-Asn-His-Asp) activity. In casein hydrolyzate, obtained under the thermolysin action, three biologically active peptides were found, two of which are immunomodulatory (Lys-Val-Leu-Pro-Val-Pro-Glu and Leu-Leu-Tyr) and one is antioxidant (Lys-Glu).

3. The optimal method of separation and purificatio of biologically active peptides [13, 14], containing in casein hydrolyzates, was chosen. The following scheme is recommended for deriving and purifying biologically active peptides from casein enzymic hydrolyzate: successive ultrafilration stages on the device MFU-R-45-300, preparative electrophoresis stages in $12.5 \%$ polyacrylamide gel in the chamber, produced by the company Bio-Rad and reversed-phase high-performance liquid chromatography stages on chromatograph LC-20. In this case the purity degree of biologically active peptides, derived from casein trypsin hydrolyzate, is within the range of $86.7-92.4 \%$; from casein chymotrypsin hydrolyzate the degree is within the range of $88.9-95.4 \%$; from thermolysin hydrolyzate the degree is within the range of $85.2-97.6 \%$.

4. Immunomodulatory, cytotoxic, antioxidant and prebiotic qualities of biologically active peptides, derived from milk proteins, are studied. It was found that all peptides under study have a cytotoxic quality, at the same time increase in biopeptide concentration causes decrease in the capacity for survival of cancer cells of different lines. Biologically active peptide with the composition Trp-Tre-Ala-Glu-Glu-Lys-Glu-Leu, derived from trypsin hydrolyzate, is characterised by the most pronounced cytotoxic activity in relation to MCF7, 6HepG2 and PANC-1 cell lines. Biologically active peptide with the composition Leu-Leu-Tyr-GluGlu-Pro-Val-Leu-Gly-Pro-Val-Gly-Pro-Pro-Pro-Ile-IleVal, derived from trypsin hydrolyzate, is characterised by the most pronounced cytotoxic activity in relation to DU 145, MDAMB-231 and 6HepG2 cell lines. Biologically active peptide with the composition TyrPro-Pro-Pro-Gly-Pro-Ile, derived from chymotrypsin hydrolyzate, is characterised by the most pronounced cytotoxic activity in relation to LBR2, MDAMB-231, 6HepG2 and PANC-1 cell lines.

Biologically active peptide with the composition Lys-Glu-Asn, derived from chymotrypsin hydrolyzate, is characterised by the most pronounced cytotoxic activity in relation to DU 145, MCF7 and 6HepG2 cell lines. Biologically active peptide with the composition Tre-Gly-Glu-Asn-His-Asp, derived from chymotrypsin hydrolyzate, is characterised by the most pronounced cytotoxic activity in relation to MDAMB-231, 6HepG2 and $\mathrm{U}-87$ cell lines. Biologically active peptide with the composition Lys-Glu, derived from thermolysin hydrolyzate, is characterised by the most pronounced cytotoxic activity in relation to LBR2, MDAMB-231 and U-87 cell lines. Biologically active peptide with the composition Lys-Val-Leu-Pro-Val-Pro-Glu, derived from thermolysin hydrolyzate, is characterised by the 
most pronounced cytotoxic activity in relation to DU 145, MDAMB-231 and 6HepG2 cell lines. Biologically active peptide with the composition Leu-Leu-Tyr, derived from thermolysin hydrolyzate, is characterised by the most pronounced cytotoxic activity in relation to LBR2, DU 145 and MDAMB-231 cell lines.

5. It is demonstrated that all the considered peptides, derived from casein trypsin, chymotrypsin and thermolysin hydrolyzates, are characterised by the pronounced antioxidant qualities: the trolox-equivalent value for biopeptide with the composition Trp-Tre-AlaGlu-Glu-Lys-Glu-Leu is within the range of 487-1345; for biopeptide with the composition Leu-Leu-Tyr-GluGlu-Pro-Val-Leu-Gly-Pro-Val-Gly-Pro-Pro-Pro-IleIle-Val the value is within the range of 505-1287; for biopeptide with the composition Tyr-Pro-Pro-Pro-GlyPro-Ile the value is within the range of 490-1400; for biopeptide with the composition Lys-Glu-Asn the value is within the range of 513-1454; for biopeptide with the composition Tre-Gly-Glu-Asn-His-Asp the value is within the range of 475-1325; for biopeptide with the composition Lys-Glu the value is within the range of 521-1500; for biopeptide with the composition LysVal-Leu-Pro-Val-Pro-Glu the value is within the range of 509-1498; for biopeptide with the composition LeuLeu-Tyr the value is within the range of 501-1432.

6. Analysis of the considered peptides prebiotic activity demonstrated that peptides of the composition Lys-Glu, Lys-Glu-Asn and Lys-Val-Leu-Pro-Val-ProGlu have the greatest impact on bifidobacteria growth, peptides of the composition Lys-Val-Leu-Pro-Val-ProGlu, Lys-Glu and Leu-Leu-Tyr have the greatest impact on lactobacilli growth. It is demonstrated that prebiotic index value for biologically active peptides under study, derived from milk proteins, varies within the range of 0.95-1.75, consequently, all peptides showed prebiotic influence on gastrointestinal tract microbiota

7. At study of biologically active peptides immunomodulatory qualities in vivo, it was found that all the considered biologically active peptides, derived from milk proteins, increase the number of cells producing antibodies in rat spleen by $1.25-1.33$ times in comparison with control. In equivalent to $1 \mathrm{~m}$ splenocytes biologically active peptides under study stimulate antibody production. Based on the absolute phagocytic index analysis, it was found that all the considered biologically active peptides, derived from milk proteins, have the capacity of stimulating phagocytosis.

\section{ACKNOWLEDGEMENTS}

The studies were conducted in conjunction with the Karolinska Institute (Stockholm, Sweden) within the framework of the Agreement No.14.586.21.0002 «Sozdanie funkcional'nyh produktov pitaniya dlya reabilitatsii onkologicheskih bol'nyh na osnove nizkomolekulyarnyh bioaktivnyh peptidnyh kompleksov i probioticheskih shtammov, vydelennyh iz zheludochno-kishechnogo trakta cheloveka» [Working out functional foodstuffs for cancer patients, based on low-molecular-weight bioactive peptide complexes and probiotic strains derived from human gastrointestinal tract], dated as of September 17, 2014 (the unique identifier of the Agreement is RFMEFI58614X0002)

\section{REFERENCES}

1. Erpulov Yu.V. Smesi na osnove peptidov u bol'nyh s patologiei zheludochno-kishechnogo trakta: sovremennye pozicii [Peptidebased formulae for patients with gastrointestinal tract pathology: the modern positions]. Lechashhiy Vrach [Attending doctor], 2008, no. 2, pp. 80-81.

3. Razumnikova I.S., Kozlova A.V. Doroganova, G.A., Avetisyan O.V. Perspektivnyi podhod k sozdaniyu produktov spetsial'nogo naznacheniya dlya profilaktiki gipertonicheskoi bolezni i hronicheskoi serdechnoi nedostatochnosti [A promising approach to the creation of special products for the hypertension and chronic heart failure prevention]. Tehnika i tehnologiya pishhevyh proizvodstv [Food production technique and technology], 2010, vol. 16 no. 1, pp. 39-43.

4. Sel'chyuk V.Yu., Manzyuk L.V., Snegova A.V., Saltanov A.I. Nutritivnaya nedostatochnost' u onkologicheskih bol'nyh: principy korrekcii [Nutritional deficiency for patients with cancer: correction principles]. Russkiy meditsinskiy zhurnal [The Russian medical journal], 2013, no. 1, pp. 14-21.

5. Kaznacheev K.S. Korrekciya nutritivnoi nedostatochnosti u detei s ostrym limfoblastnym leikozom [Nutritional deficiency correction for children with acute lymphoblastic leukemia]. Russkiy meditsinskiy zhurnal [The Russian medical journal], 2007, no. 25, pp. 1880-1891.

6. Pokrovskiy A.A. O biologicheskoi i pishhevoi cennosti produktov pitaniya [About biological and nutritional value of foodstuffs]. Voprosy pitaniya [Nutrition questions], 1975, no. 3, pp. 25-35.

7. Rybakova E.P., Byshyeva T.V., Ladodo K.S. Dietoterapiya nasledstvennyh narushenii aminokislotnogo obmena [Diet therapy of hereditary amino acid exchange deficiencies]. Voprosy detskoi dietologii [Children nutrition questions], 2005, vol. 3, no. 1, pp. 11-17.

8. Prosekov A.Yu. Poluchenie fermentativnyh gidrolizatov belkov molochnoi syvorotki s ispol'zovaniem proteoliticheskih fermentov [Deriving milk serum proteins enzymic hydrolyzates with the use of proteolytic enzymes]. Fundamental'nye issledovaniya. Tehnicheskie nauki [Fundamental studies. Technical sciences], 2013, no. 6, pp. 1089-1093.

9. Yankovskaya P.A. Aspekty nutritivnoi podderzhki onkologicheskih bol'nyh poluelementnymi smesjami [Aspects of nutritional support for patients with cancer by semi-element formulae]. Lechashhiy Vrach [Attending doctor], 2010, no. 02, pp. 80-83.

10. Pokrovskiy A.A. Belki odnokletochnyh. Mediko-biologicheskaya ocenka i perspektivy ispol'zovaniya [Proteins of unicellular organisms. Medico-biological assessment and prospects of use]. Moscow: AMN SSSR Publ., 1971. 83 p.

11. Lehninger A. Biochemistry principles. Moscow. Mir Publ., 1985. 367 p.

12. Chernikov M.P. Proteoliz i biologicheskaya cennost' belkov. Kazeiny kak sobstvenno pishhevye belki [Proteolysis and proteins biological value. Caseins as nutritional proteins]. Moscow: Meditsina Publ., 1975. 231 p. 
13. Rybakova E.V. Vysokoeffektivnaya ionnaya i zhidkostnaya hromatografiya dlya analiza produktov pitaniya dlya detei [Highperformance ionic and liquid chromatography for analysis of foodstuffs for children]. Pishhevaya promyshlennost' [Food industry], 2005, no. 3, pp. 24-26.

14. Zauer H. Immunologicheskie metody [Immunologic methods]. Moscow. 1987. 370 p.

15. Gibson, G.R. Molecular biological methods for studying the gut microbiota: the EU human gut flora project. Br. J. Nutr., 2002, vol. 87, pp. 203-211.

16. Kleessen B., Hartman L., Blaut M. Oligofructose and long chain inulin influence the gut microbial ecology of rats associared with a human faecal flora. Br J Nutr., 2001, vol. 86, pp. 291-300.

17. Roberfroid M. Prebiotics: The Concept Revisited. J. Nutr.,2007, vol. 137, no. 3, pp. 830-837.

18. Yamaue H. Chemosensitivity testing with Highly purified fresh human tumor cells with the MTT - colorimetric assay. Europ. $J$. Cancer, 1991, vol. 27, no. 10, pp. 1258-1263.

19. Rybakina E. Cellular mechanisms of cold stress-related immunosuppression and the action of interleukin. Int J Tissue React, 1997, vol. 19 , no. 3, pp. 135-140.

20. Cao G.H., Alessio H.M., Cutler R.G. Oxygen Radical Absorbency Capacity Assay for Antioxidants. Free Radicals In Biology And Medicine, 1993, vol. 3, no. 14, pp. 303-311.

21. Cao G., Verdon C.P., Wu A.H.B., Wang H., Prior R.L. Automated-Assay of Oxygen Radical Absorbency Capacity with the Cobas Fara-Ii. Clinical Chemistry, 1995, vol. 41, pp. 1738-1744.

22. Ehlenfeldt M.K. Oxygen radical absorbance capacity (ORAC) and phenolic and anthocyanin concentrations in fruit and leaf tissues of highbush blueberry. Journal of Agricultural and Food Chemistry, 2001, vol. 49, pp. 2222-2227.

23. Prosekov A. Yu., Babich O.O., Bespomestnykh K.V. Identification of industrially important lactic acid bacteria in foodstuffs. Foods and Raw Materials, 2013, vol. 2, pp. 42-45. doi: 10.12737/2053.

24. Prosekov A., Babich O., Dyshlyuk L., Belova D. Comparative analysis of physical and chemical properties of biodegradable edible films of various compositions. Journal of Food Process Engineering, 2015, pp. 1-10. doi: 10.1111/jfpe.12331.

25. Surkov I.V., Prosekov A.Yu., Ermolaeva E.O., Gorelikova G.A., Poznyakovskiy V.M. Evaluation and preventing measures of technological risks of food production. Modern Applied Science, 2015, vol. 9, no. 4, pp. 45-52.

\section{Irina S. Milenteva}

Cand.Sci.(Eng.) Senior Research Fellow at Research-Educational Center, Kemerovo Institute of Food Science and Technology (University), Kemerovo, Russia Federation

\section{Lyubov S. Dyshlyuk}

Cand.Sci.(Biol.), Head of Research-Educational Center, Kemerovo Institute of Food Science and Technology

(University), Kemerovo, Russia Federation

\section{Alexandr Yu. Prosekov}

Dr.Sci.(Eng.), Professor, Acting Rector of Kemerovo State University, Kemerovo, Russian Federation

\section{Olga O. Babich}

Dr.Sci.(Eng.), Professor, Vice-Rector for Science and Innovations of Kemerovo State University, Kemerovo, Russian Federation

\section{Mikhail V. Shishin}

Bionanotechnology Department Postgraduate, Kemerovo Institute of Food Science and Technology (University), Kemerovo, Russia Federation 